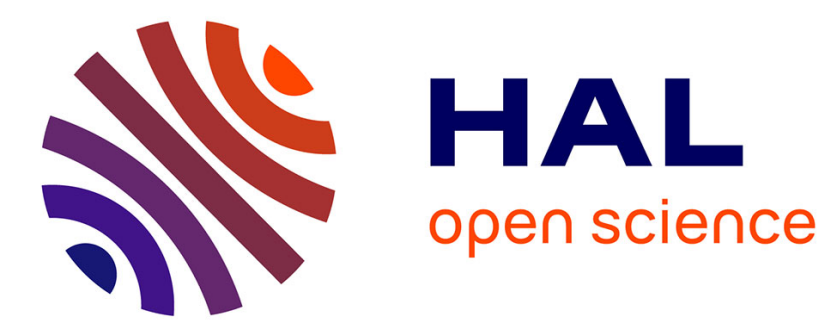

\title{
Plasma $\beta$-amyloid 40 levels are positively associated with mortality risks in the elderly.
}

Audrey Gabelle, Susanna Schraen, Laure-Anne Gutierrez, Cecile Pays, Olivier

Rouaud, Luc Buée, Jacques Touchon, Catherine Helmer, Jean-Charles

Lambert, Claudine Berr

\section{To cite this version:}

Audrey Gabelle, Susanna Schraen, Laure-Anne Gutierrez, Cecile Pays, Olivier Rouaud, et al.. Plasma $\beta$-amyloid 40 levels are positively associated with mortality risks in the elderly.. Alzheimer's \& Dementia : the Journal of the Alzheimer's Association, 2015, 11 (6), pp.672-80. 10.1016/j.jalz.2014.04.515 . inserm-01024830

\section{HAL Id: inserm-01024830 https://www.hal.inserm.fr/inserm-01024830}

Submitted on 16 Jul 2014

HAL is a multi-disciplinary open access archive for the deposit and dissemination of scientific research documents, whether they are published or not. The documents may come from teaching and research institutions in France or abroad, or from public or private research centers.
L'archive ouverte pluridisciplinaire HAL, est destinée au dépôt et à la diffusion de documents scientifiques de niveau recherche, publiés ou non, émanant des établissements d'enseignement et de recherche français ou étrangers, des laboratoires publics ou privés. 


\section{Title page}

\section{Plasma ßamyloid 40 levels are positively associated with mortality risks in the elderly}

\section{Authors}

Audrey Gabelle, Susanna Schraen, Laure-Anne Gutierrez, Cecile Pays, Olivier Rouaud, Luc Buée, Jacques Touchon, Catherine Helmer, Jean-Charles Lambert, Claudine Berr.

\section{Authors' affiliations}

Audrey Gabelle associate professor from the Centre Mémoire Ressources Recherche Languedoc-Roussillon, CHRU Gui de Chauliac Hospital, Department of Neurology, 34295 Montpellier Cedex 5, France and University Montpellier 1, F-34000 Montpellier, France; Susanna Schraen associate professor from Université Droit et Santé de Lille, F-59000 Lille, France; and CHRU de Lille, F-59037 Lille, France; and INSERM UMR837, 59045 Lille, France; Laure-Anne Gutierrez statistician from INSERM U1061, Hôpital La Colombière, F34093 Montpellier, France; Cecile Pays general practitioner from Centre Mémoire Ressources Recherche Languedoc-Roussillon, CHRU Gui de Chauliac Hospital, Department of Neurology, 34295 Montpellier Cedex 5, France and INSERM U1061, Hôpital La Colombière, F-34093 Montpellier, France ; Olivier Rouaud professor from Centre Mémoire Ressources Recherche, CHRU Dijon, Department of Neurology, F-21033 Dijon, France ; Luc Buée research director from Université Droit et Santé de Lille, F-59000 Lille, France; and CHRU de Lille, F-59037 Lille, France; and INSERM UMR837, 59045 Lille, France ; Jacques Touchon professor from the Centre Mémoire Ressources Recherche LanguedocRoussillon, CHRU Gui de Chauliac Hospital, Department of Neurology, 34295 Montpellier 
Cedex 5, France and INSERM U1061, Hôpital La Colombière, F-34093 Montpellier, France ;

Catherine Helmer researcher from INSERM 897; ISPED, Victor Segalen University, F33076, Bordeaux, France ; Jean-Charles Lambert research director from INSERM U744, F59019 Lille, France, and Institut Pasteur de Lille, F-59019 Lille, France and Université de Lille Nord de France, F-59000 Lille, France, and CHRU de Lille, F-59000 Lille, France ; Claudine Berr research director from Centre Mémoire Ressources Recherche LanguedocRoussillon, CHRU Gui de Chauliac Hospital, Department of Neurology, 34295 Montpellier Cedex 5, France and INSERM U1061, Hôpital La Colombière, F-34093 Montpellier, France.

Corresponding author and reprint requests to Dr Claudine BERR, INSERM U1061 Hôpital La Colombière, F-34093 Montpellier Cedex 5, France. Phone: 33 (0)4 996145 66; Fax : 33 (0)4 996145 79. @ address: claudine.berr@inserm.fr

Number of characters in the title: 85; Abstract: 150 words; Text: 2827 words; 4 Tables, 2 Figures, 51 references. 


\section{Abstract}

Background: We evaluated if plasma $A \beta$ levels were associated with mortality risks in a subsample of the French Three-City (3C) prospective cohort study.

Methods: Analyses were based on 1254 participants randomly selected from the initial 3C cohort stratified by center, sex and age in the context of a nested case-cohort study to investigate biological variables. Associations between plasma $\mathrm{A} \beta$ and mortality were assessed with the Cox regression model with delayed entry including various potential confounding factors and testing possible mediators.

Results: A relationship between high plasma $A \beta_{1-40}$ concentrations and risk of mortality (HR 1.15; 95\% CI [1.01-1.31], $\mathrm{p}=0.03$ ) was unveiled independently from age, educational level, vascular risk factors, diet, physical activity, cognitive impairment or frailty status. It was only modified when we included Cystatin C levels.

Conclusions: Further investigations are needed to determine precisely the pathophysiological roles of plasma $A \beta_{1-40}$ and Cystatin $C$ and before envisioning any future clinical applications. 


\section{Background}

The role of plasma $\beta$-amyloid biomarkers has been increasingly reported in Alzheimer's disease (AD) diagnosis and prognosis of cognitive decline both in vascular and neurodegenerative amyloidopathies ${ }^{1-8}$. From the onset of neurodegenerative disorders throughout the temporal freeze of the AD process, ${ }^{9}{ }^{10}$, it seems clear that cerebrospinal fluid (CSF) and plasma amyloid markers are highly relevant regardless of the stage of the disease: from memory complaints to loss of autonomy status and/or mortality ${ }^{1}$. In order to improve diagnostic criteria at an early stage, some studies have focused on determining $A \beta$ markers profile in population-based studies in subjects free of cognitive impairment as well as the curve of plasma $\beta$-amyloid concentrations over a person's lifetime and prognostic usefulness of plasma $\beta$-amyloid biomarkers in aging populations.

This domain raises new questions about the role of amyloid biomarkers in terms of the gaining prognosis. Surprisingly, very little is known about the physiological "role" of amyloid in plasma. As described in a few studies, concentrations of amyloid peptides increase with age ${ }^{11-13}$. The ratio between the two forms $A \beta_{1-40}$ and $A \beta_{1-42}$ is inversely associated with blood pressure values and risk of hypertension in the elderly ${ }^{14}$ and also with depression ${ }^{15}$. Vascular risk factors including cholesterol and $\mathrm{HbAlc}$ are associated with higher concentrations of $\mathrm{A} \beta_{1-42}{ }^{16}$. A recent report has suggested that higher dietary intakes of $\omega 3$-Poly-Unsaturated Fatty Acids were associated with lower plasma concentrations of $A \beta_{1-42}$ in cognitively healthy elderly subjects ${ }^{17}$.

It has been hypothesized that high plasma amyloid level was associated with mortality. To address this issue, we studied whether plasma $A \beta$ concentrations were associated with mortality risk in a subsample of the French Three-City (3C) prospective cohort study of men and women aged 65 and over. Being in this cohort framework enabled us to test if this 
association was independent from other factors previously linked to plasma $A \beta$ concentrations and to potential mediators.

\section{Methods}

The study design, population and methods used have been described in our accompanying paper. Details of the 3C (three French cities: Bordeaux, Montpellier and Dijon) population-based prospective study were also previously published ${ }^{318}$. Analyses were based on 1254 participants randomly selected from the initial cohort and stratified by center, sex and age in the frame of a nested case-cohort study to investigate biological variables (Figure 1, flow chart). Baseline amyloid concentrations were available for 1244 of them. We also ended up excluding 73 subjects for whom data on confounding factors were missing as well as 24 prevalent dementia cases diagnosed according to the Diagnostic and Statistical Manual of Mental Disorders (DSM-IV) criteria.

The standardized interview included questions on sociodemographic and lifestyle characteristics including hypertension, diabetes, history of vascular pathologies (stroke, angina pectoris, myocardial infarction and cardio-vascular surgery), diet (fruit, vegetables, fish, olive oil consumption), physical activity and chronic respiratory disorders as well as an inventory of all drugs used. For each participants, MCI status at baseline was defined according to the revised algorithm (MCI-R) based on a cross-sectional evaluation as suggested by an international consensus group ${ }^{19}$. In a subsample of the cohort (Bordeaux and Dijon centers), physical frailty was defined according to the Fried frailty criteria ${ }^{20}$, as indicated by the presence of at least three of the following criteria: weight loss, weakness, exhaustion, slowness and low activity level ${ }^{21}$.

The plasma $\mathrm{A} \beta$ peptide assay was performed using the INNO-BIA kit (Innogenetics, Ghent, Belgium), based on a multiplex xMAP technique with a LABScan-100 system 
(Luminex BV, The Netherlands). Analyses were performed in a unique centralized laboratory in Lille (SS, LB). Fibrinogen was measured using the kinetic method of Clauss (Dade Behring, Paris, France), fibrin D-dimer by ELISAs from Diagnostica Stago (Asserachrom VWF and D-Di; Asnières-sur-Seine, France). As previously described ${ }^{22}$ we used equations to standardize all serum creatinine values from the Jaffe assay to obtain IDMS- traceable measurements. Then, we estimated eGFR in $\mathrm{mL} / \mathrm{min} / 1.73 \mathrm{~m}^{2}$ using the CKD-EPI equation. Cystatin $\mathrm{C}$ factor was measured with the turbidimetric method based on measurements of immunoprecipitation at 540nm with the konelab $^{\mathrm{TM}}$ analyzer (Thermo Fischer Scientific Oy, Finland).

All-cause mortality was obtained from civil registration data with a systematic request for all subjects not seen in follow-up visits. Date of point was defined as date of death or date at last follow-up or phone contact for the 8-year follow-up. Information on cause of death was obtained medical records (based on the International Classification of Diseases, version 10, ICD-10) ${ }^{23}$. Mortality from cardiovascular disease (CVD) (ICD-10: I) and cancer (ICD-10: C), the two leading causes of death in this population were considered ${ }^{24}$.

\section{Statistical analysis}

$\mathrm{A} \beta$ variables were evaluated as continuous characteristics. Comparisons between subjects who died and those who stayed alive were done with a Chi2 on the set of variables. We examined correlations between $A \beta$ variables and age or biological dosage using Spearman correlation coefficients.

Associations between $\mathrm{A} \beta$ levels and risk of mortality were determined by the Proportional Hazards Regression Model of Cox with delayed entry, where age (in years) was used for the time axis and left truncation for age at study entry. The use of time-on-study as a time scale is 
not recommended when covariates of interest are strongly associated with age; which is clearly the case for amyloid dosage $\mathrm{e}^{25}$.

We validated the linearity of all quantitative variables which were included as continuous variables in the models. Assumption of proportionality (for amyloid concentrations) was tested and met in the presence of other covariates in the full model. Multivariate-adjusted models used to probe associations between $\mathrm{A} \beta$ variables (for 1 Standard Deviation change) and mortality, were tested for various potential confounders. Selected confounding factors associated with mortality $(\mathrm{p}<0.15)$ were age, gender, educational level (years of schooling), occupation, body mass index (BMI), history of chronic disorders, depression, limitations of instrumental activities of daily living (IADL), olive oil consumption, physical frailty, Cystatin $\mathrm{C}$, fibrinogen and plasma $A \beta_{1-40}$. Although they were not significant we also added the study center, alcohol consumption, smoking habits, hypertension, fish intake, fruits and vegetables intake and physical activity to the models as they were associated with mortality for the whole sample. ApoE was not related to mortality $(\mathrm{p}=0.39)$ and thus was not included in the models. The model named BASIC was adjusted for age (timescale), gender and study center. The CLASSIC CONFOUNDERS model also included educational level, occupation, BMI, smoking status, alcohol, history of chronic disorders, hypertension, depression, IADL, fruits and vegetables, fish, olive oil intake and physical activity.

Secondly, we tested the possible mediation effect of cognitive status and physical frailty in these elderly subjects based on two indicators: cognitive status (defined by MCI status at baseline, model MCI) and physical frailty defined only on a subsample (FRAILTY Model). Furthermore, we examined whether associations between plasma amyloid marker and mortality observed in the CLASSIC CONFOUNDERS model were mediated by biological determinants. First, we studied renal functions through eGFR (under or over $60 \mathrm{mg} / \mathrm{ml}$ ) (Model KIDNEY FUNCTIONS). The role of systemic inflammation measured by fibrinogen 
was assessed (Model FIBRINOGEN). Finally, Cystatin C factor, related to renal functions and CSF amyloid metabolism was considered as a potential mediating factor (Model CYSTATIN C).

Analyses were performed using SAS software (version 9.2, SAS Institute Inc., Cary, NC).

\section{Results}

Baseline Characteristics (Table 1). During the 8675 person-years of observation in a total of 1147 subjects, 215 deaths (mean follow-up 5.7 years $\mathrm{SD}=2.6$ ) were registered while 932 participants remained alive (mean follow-up 8.0 years $\mathrm{SD}=1.4$ ). The subjects who died were predominantly men $(\mathrm{p}<0.0001)$, older $(\mathrm{p}<0.0001)$ and current or former smoker $(\mathrm{p}=0.01)$. They more often had a history of chronic disorders $(\mathrm{p}<0.0001)$, hypertension $(\mathrm{p}=0.01)$ and IADL impairment $(\mathrm{p}<0.0001)$. They were less often fish consumers $(\mathrm{p}=0.05)$, olive oil consumers $(\mathrm{p}=0.01)$ and practiced less physical activity $(\mathrm{p}=0.01)$. They had higher level of fibrinogen $(3.49 \mathrm{~g} / \mathrm{L}$ vs. 3.31, $\mathrm{p}=0.01)$ and Cystatin $\mathrm{C}(0.99$ unit vs. $0.87, \mathrm{p}<0.0001)$ and lower e-GFR $\left(71.5 \mathrm{~mL} / \mathrm{mn} / 1.73 \mathrm{~m}^{2}\right.$ vs. $\left.76.7, \mathrm{p}<0.0001\right)$. Plasma $\mathrm{A} \beta_{1-40}$ concentrations increased with age $(\mathrm{r}=0.19, \mathrm{p}<0.0001)$ and were correlated with biological factors linked to renal functions such as Cystatin C $(r=0.30, p<0.0001)$ and e-GFR $(r=-0.31, p<0.0001)$ but not with fibrinogen $(r=0.03, p=0.27)$. Similar associations were shown for $A \beta_{1-42}$ concentrations, respectively: Age $(r=0.08, \mathrm{p}=0.005)$, Cystatin $\mathrm{C}(\mathrm{r}=0.19, \mathrm{p}<0.0001)$, e-GFR $(\mathrm{r}=-0.23$, $\mathrm{p}<0.0001)$ and fibrinogen $(\mathrm{r}=0.05, \mathrm{p}=0.07)$. Cystatin $\mathrm{C}$ is highly correlated to e-GFR $(\mathrm{r}=-0.59$, $\mathrm{p}<0.0001)$. All correlations are presented in Table 2.

Plasma $A \beta$ concentrations associated with mortality.

Baseline $A \beta_{1-40}$ level and $A \beta_{1-40} / 1-42$ ratio were significantly higher in the plasma samples of deceased subjects than in survivors' samples (mean $A \beta_{1-40}=247.7 \mathrm{pg} / \mathrm{mL}$ vs. $229.7 \mathrm{pg} / \mathrm{mL}$, 
$\mathrm{p}<0.0001$ and mean $\mathrm{A} \beta_{1-40} / 1_{1-42}=6.7$ vs. 6.3, $\left.\mathrm{p}=0.03\right)$. The Kaplan-Meier survival curves (Figure 2) graphically show the crude difference in survival between subjects according to their $A \beta 1-40$ level (above or under the tertile 3 cut-off). A gradient of mortality risk was evident for an increase of $1 \mathrm{SD}$ of $\mathrm{A} \beta_{1-40}$ plasma level and $\mathrm{A} \beta_{1-40} /{ }_{1-42}$ ratio at baseline (Table 3) taking into account factors known to be involved in mortality (Model BASIC and CLASSIC CONFOUNDERS). No difference was observed for $A \beta_{1-42}$ regardless of the survival curve or models.

Association of plasma $A \beta$ concentrations with cause-specific mortality.

Regarding cause-specific mortality, baseline A $\beta 1-40$ level was associated with mortality from cancer (Model CLASSIC CONFOUNDERS n=76, HR=1.26, 95\% CI: 1.02-1.57, p=0.04) and to a lesser extent with mortality from $\operatorname{CVD}(\mathrm{n}=44, \mathrm{HR}=1.30,95 \% \mathrm{CI}: 0.97 ; 1.73, \mathrm{p}=0.08)$. No difference was observed for $A \beta 1-42$ or $A \beta 1-40 / 1-42$ ratio regardless of the specific cause.

$\underline{\text { Is the association between plasma } A \beta_{1-40} \text { concentrations and mortality explained by cognitive }}$ status and/or physical frailty? (Table 4)

Adjusting for MCI, our primary results were not modified for plasma $\mathrm{A} \beta_{1-40}(\mathrm{HR}=1.15 ; 95 \%$ CI [1.02-1.31], $\mathrm{p}=0.03$ ) or for $\mathrm{A} \beta_{1-40} / 1-42$ ratio (HR 1.08; CI 95\% [1.02-1.15], $\mathrm{p}=0.01$ ). Adjusting for physical frailty did not substantially alter the observed correlations between mortality and plasma $\mathrm{A} \beta_{1-40}(\mathrm{HR}=1.21 ; 95 \% \mathrm{CI}[1.04-1.40], \mathrm{p}=0.02)$ or the $\mathrm{A} \beta_{1-40} /{ }_{1-42}$ ratio (HR 1.09; CI 95\% [1.02-1.17], $\mathrm{p}=0.02)$.

$\underline{\text { Are correlations between plasma } \mathrm{A} \beta \text { concentrations and mortality explained by biological }}$ systemic abnormalities? (Table 4) 
The association between risk of mortality and plasma $A \beta$ concentrations was not modified by the macroscopic inflammatory process measured by fibrinogen (Model FIBRINOGEN), or kidney functions analyzed by e-GFR (Model KIDNEY FUNCTION). Associations between plasma $A \beta_{1-40}$ and mortality were partially explained by the Cystatin $C$ level $\left(A \beta_{1-40}\right.$ : HR 1.10; CI 95\% [0.96-1.25], p=0.17; Model CYSTATIN C). Additional adjustments on fibrinogen or e-GFR did not change the CYSTATIN C model results (data not shown).

\section{Discussion}

To the best of our knowledge, this is the first report highlighting that plasma concentrations of $\mathrm{A} \beta_{1-40}$ and $\mathrm{A} \beta_{1-40} /_{1-42}$ ratio are associated with an increased risk of mortality in the elderly. Our study also brings forward arguments to try and answer the central question raised by our analyses: How can we explain such a relationship?

One of the first explanations might be that elderly subjects presented intra-cerebral lesions of $\mathrm{AD}$ at a prodromal stage of the disease, since we know that AD-related pathophysiological changes can occur many years before the onset of clinical dementia syndrome. First, we excluded all prevalent dementia cases from the analysis sample $(\mathrm{n}=24)$ and our complementary analyses did not validate this point.

When the Alzheimer's process is taken into account by including in all models baseline MCI status, the relationships between plasma amyloid $A \beta_{1-40}$ and $A \beta_{1-40} / 1-42$ ratio and risk of mortality were not modified. Additionally, the pathological link between plasma $A \beta_{1-40}$ concentrations and mortality was not observed for the $\mathrm{A} \beta_{1-42}$ isoform, which is specifically altered in the Alzheimer's process. In the complementary analysis we also excluded the 72 incident dementia cases (Alzheimer's disease and other dementia), confirming the absence of an association between $A \beta_{1-42}$ and mortality which was previously evidenced in the Northern Manathan cohort in a three-year follow-up ${ }^{1}$. 
Another explanation for this association between plasma $\beta$-amyloid level and mortality risk in elderly subjects might be frailty. Frailty has been associated with an increased risk of death or adverse clinical outcomes independently of cognitive impairment ${ }^{21} 26-29$. Even though the potential association between frailty and plasma $\beta$-amyloid has not yet been observed in our sample (data not shown), some elements pointed to this possibility. Recently, $\beta-2-$ microglobulin has been described as a marker of frailty in older adult ${ }^{30}$. Interestingly, $\beta-2-$ microglobulin is known to be a component of amyloid fibrils in peripheral amyloidosis ${ }^{31} 32$ and $A \beta_{1-40}$ fragment is more involved as a potential marker in amyloidosis and peripheral or cerebral angiopathy disorders. In our population, the frailty confounding factor did not alter the relationship between mortality and plasma $A \beta_{1-40}$ levels. However, we are aware of the limits of this frailty concept and the frailty composite score used in this study. So, the hypothesis that frailty is in fact the missing link between plasma $A \beta$ level and mortality risk remains unanswered.

A mediator metabolic process either by an increased production of $\beta$-amyloid peptide via pro-inflammatory mechanisms or by a defect of the amyloid peptides clearance secondary to kidney function alteration could be another hypothesis. The notion of pro-inflammatory process caused by potential atherosclerotic lesions seems to quite relevant on many levels: (1) atherosclerosis plaques commonly seen in the elderly ${ }^{33}$; (2) the major mechanism of atherosclerosis seems to be a chronic inflammation of the vessels ${ }^{34}$; (3) chronic inflammation/atherosclerosis induces activated platelets ${ }^{34}$; (4) part of plasma $\beta$-amyloid peptides is produced by platelets in a peripheral pool; (5) both aorta and platelets contains predominantly $A \beta_{1-40}$ peptides whereas $A \beta_{1-42}$ plasma reservoir constitutes a minor contribution to atherosclerotic plaques ${ }^{34}$; (6) the $\mathrm{A} \beta_{1-40}$ fragment seems to play a pathophysiological role in disrupting endothelial vascular functions as suggested by results showing that plasma $A \beta_{1-40}$ concentrations are independently associated with the diffuse 
small-vessel disease subtype ${ }^{35}$. However, the relationship we observed is in fact independent from the inflammation process assessed through fibrinogen as biomarkers; this was also true considering CRP levels (data not shown).

Interestingly, we unveiled that the positive relationship between higher plasma $A \beta_{1-40}$ levels and increased mortality risk could be at least partially explained by the Cystatin $\mathrm{C}$ marker. Cystatin $\mathrm{C}$ belongs to the super family of the Cystatin type 2 and acts as an inhibitor of the Cystein protease (ie Cathepsins). Cystatin $\mathrm{C}$ is known to modulate the inflammatory response $^{36}$ and can be considered as a systemic inflammatory marker. However, further adjustments on fibrinogen did not modify the model CYSTATIN results. Secondly, we could have imagined that since Cystatin $\mathrm{C}$ was exploring kidney functions ${ }^{37}$ it might be implied in the renal clearance of amyloid- $\beta$ peptide. However, this link seems to be independent from kidney function alterations, as validated by the e-GFR. There is also evidence of Cystatin C role in $\mathrm{A} \beta$ metabolism and development of clinical $\mathrm{AD}^{38}$. Cystatin has been shown to be involved in $\mathrm{A} \beta$ metabolism through different mechanisms, regulating soluble $\mathrm{A} \beta$ concentrations as transporter of soluble $\mathrm{A} \beta$ isoforms ${ }^{39}$ and regulating the $\mathrm{A} \beta$ fibrillization process in the brain. Cystatin $C$ interacts with both $A \beta_{1-40}$ and $A \beta_{1-42}$, via a specific and highaffinity binding ${ }^{40}$. The role of Cystatin on amyloid fibril formation was originally suggested by its co-localization with $\mathrm{A} \beta$ in senile plaques and in amyloid fibril deposits in vascular walls of $\mathrm{AD}$ brains $^{41}$. Cystatin $\mathrm{C}$ does not dissolve preformed amyloid- $\beta$ fibrils or oligomers ${ }^{40}$ ${ }^{42}$ but its association with $A \beta$ inhibits in vivo amyloid- $\beta$ oligomerization and fibril formation ${ }^{39}$ 43. Unlike a complete deletion of Cystatin C, either reduced or enhanced levels of Cystatin C expression inhibit the aggregation of amyloid- $\beta^{39} 43$. These puzzling effects on aggregation may be explained by the different mechanisms underlying Cystatin $\mathrm{C}$ regulation of soluble and insoluble $A \beta$. Finally, the effect on amyloid aggregation depends on the balance between $\mathrm{A} \beta$ species, Cystatin C levels and Cathepsin B (CatB). Based on all these arguments, how can 
we explain $A \beta$ concentrations variations in the light of Cystatin $C$ levels? An increase in plasmatic $A \beta_{1-40}$ but not $A \beta_{1-42}$ is associated with increased mortality with a correlation with Cystatin C. Increased Cystatin C inhibits degradation of amyloid peptides by CatB and can explain the increase in soluble brain $A \beta_{1-40}$ and $A \beta_{1-42}$, passing in extracellular fluids like CSF or plasma. The 40/42 ratio decreases at the limit of significance. As Cystatin C inhibits A $\beta$ oligomerization (concerning mainly $A \beta_{1-42}$ species) the amount of soluble $A \beta_{1-42}$ should increase relatively to $\mathrm{A} \beta_{1-40}$ explaining a higher $\mathrm{A} \beta_{1-42} / 1-40$ ratio.

Although our results concern a single measurement of plasma $\beta$-amyloid concentrations their relevance is reinforced by the large number of potential confounding factors documented at baseline including markers of renal function and inflammation. We controlled for many factors known to be associated with mortality or plasma A $\beta$ concentrations, such as gender ${ }^{44}$, age ${ }^{11144-46}$, educational level ${ }^{47}$, cardiovascular factors $^{444}$, hypertension ${ }^{14}$, atherosclerosis risk factors ${ }^{16}$, physical activity and $\operatorname{diet}^{48}$, depression ${ }^{15}$, body mass index ${ }^{49}$, tobacco and alcohol consumption ${ }^{50}$, diabetes and limitations in at least one of the IADL or impaired kidney functions ${ }^{44} 51$. Furthermore there was no interaction between amyloid levels and gender.

To conclude, plasma $A \beta_{1-40}$ is associated with mortality in our elderly population. Further investigations are needed to determine more precisely plasma $A \beta_{1-40}$ and Cystatin $C$ pathophysiological roles. In our era of preventive care management, the possibility of monitoring changes in plasma biomarkers after specific health/preventive interventions opens new opportunities in this field. 


\section{REFERENCES}

1. Mayeux R, Honig LS, Tang MX, Manly J, Stern Y, Schupf N, et al. Plasma $\mathrm{A}[$ beta]40 and $\mathrm{A}[\mathrm{beta}] 42$ and Alzheimer's disease: relation to age, mortality, and risk. Neurology 2003;61(9):1185-90.

2. van Oijen M, Hofman A, Soares HD, Koudstaal PJ, Breteler MM. Plasma Abeta(140) and Abeta(1-42) and the risk of dementia: a prospective case-cohort study. Lancet neurology 2006;5(8):655-60.

3. Lambert JC, Schraen-Maschke S, Richard F, Fievet N, Rouaud O, Berr C, et al. Association of plasma amyloid beta with risk of dementia: the prospective Three-City Study. Neurology 2009;73(11):847-53.

4. Seppala TT, Herukka SK, Hanninen T, Tervo S, Hallikainen M, Soininen H, et al. Plasma Abeta42 and Abeta40 as markers of cognitive change in follow-up: a prospective, longitudinal, population-based cohort study. Journal of neurology, neurosurgery, and psychiatry 2010;81(10):1123-7.

5. Lui JK, Laws SM, Li QX, Villemagne VL, Ames D, Brown B, et al. Plasma amyloidbeta as a biomarker in Alzheimer's disease: the AIBL study of aging. Journal of Alzheimer's disease : JAD 2010;20(4):1233-42.

6. Yaffe K, Weston A, Graff-Radford NR, Satterfield S, Simonsick EM, Younkin SG, et al. Association of plasma beta-amyloid level and cognitive reserve with subsequent cognitive decline. JAMA : the journal of the American Medical Association 2011;305(3):261-6.

7. Gabelle A, Richard F, Gutierrez LA, Schraen S, Delva F, Rouaud O, et al. Plasma Amyloid-beta Levels and Prognosis in Incident Dementia Cases of the 3-City Study. Journal of Alzheimer's disease : JAD 2012.

8. Hernandez-Guillamon M, Delgado P, Penalba A, Rodriguez-Luna D, Molina CA, Rovira A, et al. Plasma beta-amyloid levels in cerebral amyloid angiopathyassociated hemorrhagic stroke. Neuro-degenerative diseases 2012;10(14):320-3.

9. Dubois B, Feldman HH, Jacova C, Cummings JL, Dekosky ST, Barberger-Gateau $\mathrm{P}$, et al. Revising the definition of Alzheimer's disease: a new lexicon. Lancet neurology 2010;9(11):1118-27.

10. Jack CR, Jr., Knopman DS, Jagust WJ, Shaw LM, Aisen PS, Weiner MW, et al. Hypothetical model of dynamic biomarkers of the Alzheimer's pathological cascade. Lancet neurology 2010;9(1):119-28.

11. Smith CC, Betteridge DJ. Plasma beta-amyloid (A beta) 40 concentration, lipid status and age in humans. Neuroscience letters 2004;367(1):48-50.

12. Fukumoto H, Tennis M, Locascio JJ, Hyman BT, Growdon JH, Irizarry MC. Age but not diagnosis is the main predictor of plasma amyloid beta-protein levels. Archives of neurology 2003;60(7):958-64.

13. Metti AL, Cauley JA, Ayonayon HN, Harris TB, Rosano C, Williamson JD, et al. The Demographic and Medical Correlates of Plasma Abeta40 and Abeta42. Alzheimer disease and associated disorders 2012.

14. Lambert JC, Dallongeville J, Ellis KA, Schraen-Maschke S, Lui J, Laws S, et al. Association of plasma Ass peptides with blood pressure in the elderly. PloS one 2011;6(4):e18536.

15. Metti AL, Cauley JA, Newman AB, Ayonayon HN, Barry LC, Kuller LM, et al. Plasma Beta Amyloid Level and Depression in Older Adults. The journals of gerontology. Series A, Biological sciences and medical sciences 2012. 
16. Blasko I, Kemmler G, Jungwirth S, Wichart I, Weissgram S, Jellinger K, et al. Prospective study on association between plasma amyloid beta-42 and atherosclerotic risk factors. J Neural Transm 2011;118(5):663-72.

17. Gu Y, Schupf N, Cosentino SA, Luchsinger JA, Scarmeas N. Nutrient intake and plasma beta-amyloid. Neurology 2012;78(23):1832-40.

18. Vascular factors and risk of dementia: design of the Three-City Study and baseline characteristics of the study population. Neuroepidemiology 2003;22(6):316-25.

19. Artero S, Ancelin ML, Portet F, Dupuy A, Berr C, Dartigues JF, et al. Risk profiles for mild cognitive impairment and progression to dementia are gender specific. J Neurol Neurosurg Psychiatry 2008.

20. Fried LP, Tangen CM, Walston J, Newman AB, Hirsch C, Gottdiener J, et al. Frailty in older adults: evidence for a phenotype. The journals of gerontology. Series A, Biological sciences and medical sciences 2001;56(3):M146-56.

21. Avila-Funes JA, Helmer $C$, Amieva $H$, Barberger-Gateau $P$, Le Goff $M$, Ritchie K, et al. Frailty among community-dwelling elderly people in France: the threecity study. The journals of gerontology. Series A, Biological sciences and medical sciences 2008;63(10):1089-96.

22. Breton G, Froissart M, Janus N, Launay-Vacher V, Berr C, Tzourio C, et al. Inappropriate drug use and mortality in community-dwelling elderly with impaired kidney function--the Three-City population-based study. Nephrology, dialysis, transplantation : official publication of the European Dialysis and Transplant Association - European Renal Association 2011;26(9):2852-9.

23. World Health Organisation. International Classification of Diseases And Related Health Problems (ICD-10): WHO, 1992.

24. Alperovitch A, Bertrand M, Jougla E, Vidal JS, Ducimetiere P, Helmer C, et al. Do we really know the cause of death of the very old? Comparison between official mortality statistics and cohort study classification. Eur $J$ Epidemiol 2009.

25. Thiebaut AC, Benichou J. Choice of time-scale in Cox's model analysis of epidemiologic cohort data: a simulation study. Statistics in medicine 2004;23(24):3803-20.

26. Pilotto A, Rengo F, Marchionni N, Sancarlo D, Fontana A, Panza F, et al. Comparing the prognostic accuracy for all-cause mortality of frailty instruments: a multicentre 1-year follow-up in hospitalized older patients. PloS one 2012;7(1):e29090.

27. Cano C, Samper-Ternent R, Al Snih S, Markides K, Ottenbacher KJ. Frailty and cognitive impairment as predictors of mortality in older Mexican Americans. The journal of nutrition, health \& aging 2012;16(2):142-7.

28. Bilotta C, Bergamaschini L, Nicolini P, Case A, Pina G, Rossi SV, et al. Frailty syndrome diagnosed according to the Study of Osteoporotic Fractures criteria and mortality in older outpatients suffering from Alzheimer's disease: a oneyear prospective cohort study. Aging \& mental health 2012;16(3):273-80.

29. Jacobs JM, Cohen A, Ein-Mor E, Maaravi Y, Stessman J. Frailty, cognitive impairment and mortality among the oldest old. The journal of nutrition, health \& aging 2011;15(8):678-82.

30. Annweiler C, Bataille R, Ferriere N, Douillet D, Fantino B, Beauchet O. Plasma beta-2 microglobulin as a marker of frailty in older adults: a pilot study. The journals of gerontology. Series A, Biological sciences and medical sciences 2011;66(10):1077-9. 
31. Fujimoto N, Wada N, Akiyama M, Tajima S, Ishibashi A, Miyakawa S. Coexistence of beta2 microglobulin and lambda light chain in amyloid fibrils of dialysis-unrelated plasma cell dyscrasia-associated systemic amyloidosis. The British journal of dermatology 2002;147(3):549-53.

32. Drueke TB. Beta2-microglobulin and amyloidosis. Nephrology, dialysis, transplantation : official publication of the European Dialysis and Transplant Association - European Renal Association 2000;15 Suppl 1:17-24.

33. Debette S, Lambert JC, Gariepy J, Fievet N, Tzourio C, Dartigues JF, et al. New insight into the association of apolipoprotein $\mathrm{E}$ genetic variants with carotid plaques and intima-media thickness. Stroke; a journal of cerebral circulation 2006;37(12):2917-23.

34. Kokjohn TA, Van Vickle GD, Maarouf CL, Kalback WM, Hunter JM, Daugs ID, et al. Chemical characterization of pro-inflammatory amyloid-beta peptides in human atherosclerotic lesions and platelets. Biochimica et biophysica acta 2011;1812(11):1508-14.

35. Gomis M, Sobrino T, Ois A, Millan M, Rodriguez-Campello A, Perez de la Ossa $\mathrm{N}$, et al. Plasma beta-amyloid $1-40$ is associated with the diffuse small vessel disease subtype. Stroke; a journal of cerebral circulation 2009;40(10):3197201.

36. Warfel AH, Zucker-Franklin D, Frangione B, Ghiso J. Constitutive secretion of cystatin C (gamma-trace) by monocytes and macrophages and its downregulation after stimulation. The Journal of experimental medicine 1987;166(6):1912-7.

37. Filler G, Bokenkamp A, Hofmann W, Le Bricon T, Martinez-Bru C, Grubb A. Cystatin $C$ as a marker of GFR--history, indications, and future research. Clinical biochemistry 2005;38(1):1-8.

38. Sundelof J, Arnlov J, Ingelsson E, Sundstrom J, Basu S, Zethelius B, et al. Serum cystatin $\mathrm{C}$ and the risk of Alzheimer disease in elderly men. Neurology 2008;71(14):1072-9.

39. Mi W, Jung SS, Yu H, Schmidt SD, Nixon RA, Mathews PM, et al. Complexes of amyloid-beta and cystatin $\mathrm{C}$ in the human central nervous system. Journal of Alzheimer's disease : JAD 2009;18(2):273-80.

40. Sastre M, Calero M, Pawlik M, Mathews PM, Kumar A, Danilov V, et al. Binding of cystatin $C$ to Alzheimer's amyloid beta inhibits in vitro amyloid fibril formation. Neurobiology of aging 2004;25(8):1033-43.

41. Maruyama K, Ikeda S, Ishihara T, Allsop D, Yanagisawa N. Immunohistochemical characterization of cerebrovascular amyloid in 46 autopsied cases using antibodies to beta protein and cystatin C. Stroke; a journal of cerebral circulation 1990;21(3):397-403.

42. Selenica ML, Wang X, Ostergaard-Pedersen L, Westlind-Danielsson A, Grubb A. Cystatin $C$ reduces the in vitro formation of soluble Abeta1-42 oligomers and protofibrils. Scandinavian journal of clinical and laboratory investigation 2007;67(2):179-90.

43. Kaeser SA, Herzig MC, Coomaraswamy J, Kilger E, Selenica ML, Winkler DT, et al. Cystatin $\mathrm{C}$ modulates cerebral beta-amyloidosis. Nature genetics 2007;39(12):1437-9.

44. Toledo JB, Vanderstichele H, Figurski M, Aisen PS, Petersen RC, Weiner MW, et al. Factors affecting Abeta plasma levels and their utility as biomarkers in ADNI. Acta neuropathologica 2011;122(4):401-13. 
45. Le Bastard N, Leurs J, Blomme W, De D, Pp, Engelborghs S. Plasma Amyloidbeta Forms in Alzheimer's Disease and Non-Alzheimer's Disease Patients. $J$ Alzheimers Dis 2010.

46. Lui JK, Laws SM, Li QX, Villemagne VL, Ames D, Brown B, et al. Plasma Amyloid-beta as a Biomarker in Alzheimer's Disease: The AIBL Study of Aging. J Alzheimers Dis 2010.

47. Dumurgier J, Paquet C, Benisty S, Kiffel C, Lidy C, Mouton-Liger F, et al. Inverse association between CSF Abeta 42 levels and years of education in mild form of Alzheimer's disease: the cognitive reserve theory. Neurobiology of disease 2010;40(2):456-9.

48. Sjogren P, Becker W, Warensjo E, Olsson E, Byberg L, Gustafsson IB, et al. Mediterranean and carbohydrate-restricted diets and mortality among elderly men: a cohort study in Sweden. The American journal of clinical nutrition 2010;92(4):967-74.

49. de Hollander EL, Van Zutphen M, Bogers RP, Bemelmans WJ, De Groot LC. The impact of body mass index in old age on cause-specific mortality. The journal of nutrition, health \& aging 2012;16(1):100-6.

50. Svendsen HO, Mosbech J. [Mortality of alcoholic liver cirrhosis. Diagnostic background for statistics concerning cause of death]. Ugeskrift for laeger 1976;138(31):1910-11.

51. Arvanitakis Z, Lucas JA, Younkin LH, Younkin SG, Graff-Radford NR. Serum creatinine levels correlate with plasma amyloid Beta protein. Alzheimer disease and associated disorders 2002;16(3):187-90. 


\section{Acknowledgements/Conflicts/Funding/Sources}

\section{No copyright or licence for publication.}

Funding: The 3C Study is conducted under a partnership agreement between the Institut National de la Santé et de la Recherche Médicale (INSERM), Victor-Segalen Bordeaux-2 University, and Sanofi-Aventis. The Fondation pour la Recherche Médicale funded the preparation and initiation of the study. The 3C Study is also supported by the Caisse Nationale Maladie des Travailleurs Salariés, Direction Générale de la Santé, MGEN, Institut de la Longévité, Conseils Régionaux d'Aquitaine et Bourgogne, Fondation de France and Ministry of Research - INSERM Programme «Cohortes et collections de données biologiques », Agence Nationale de la Recherche ANR PNRA 2006 and Longvie 2007 and Fonds de coopération scientifique Alzheimer (FCS 2009-2012).

Conflicts of interest: Dr. Gabelle has received funding travel expenses for AD conferences from Novartis. C. Helmer has received funding travel expenses for conferences from Ipsen, S. Schraen, C Berr, C Pays, LA Gutierrez, J Touchon reports no disclosures.

\section{Details of contributors: Individual contributions to the manuscript}

A. Gabelle: analysis and interpretation of the data; drafting /revising the manuscript.

S. Schraen: data acquisition; analysis and interpretation of the data; revising the manuscript.

L.A Gutierrez: acquisition of data; analysis and interpretation of the data; statistical analysis; drafting/revising the manuscript.

C. Pays: data acquisition; revising the manuscript.

O. Rouaud: drafting/revising the manuscript.

L. Buée: drafting/revising the manuscript. 
J. Touchon: study supervision; drafting/revising the manuscript.

C. Helmer: data acquisition, interpretation of the data; drafting/revising the manuscript.

JC. Lambert: data acquisition; study supervision; drafting/revising the manuscript.

C. Berr: data acquisition; analysis and interpretation of the data; statistical analysis; study concept; study supervision; drafting/revising the manuscript.

Name of the guarantor: C Berr

All patients gave their written informed consent to participate in this research study.

The study protocol was approved by the Ethical Committee of the Institutional Review Board at Kremlin-Bicêtre University Medical Center.

Key Words: Ageing, mortality risks, plasma amyloid markers, cystatin C, mild cognitive impairment due to Alzheimer's disease, frailty. 


\section{TABLES LEGENDS Gabelle et al., manuscript}

Table 1: Characteristics of the $3 \mathrm{C}$ sub-cohort population according to the 8 -year vital status.

\begin{tabular}{|c|c|c|c|c|}
\hline & & Alive $\mathbf{n = 9 3 2}$ & $\begin{array}{c}\text { Deceased } \\
\mathrm{n}=215\end{array}$ & $\mathbf{p}$ \\
\hline & & $\%$ & $\%$ & \\
\hline Sex & Men & 37.12 & 52.56 & $<.0001$ \\
\hline Educational level : & $\leq 5$ years & 24.03 & 22.33 & 0.45 \\
\hline & $6-9$ years & 36.37 & 37.67 & \\
\hline & $10-12$ years & 20.82 & 24.65 & \\
\hline & $>12$ & 18.78 & 15.35 & \\
\hline Occupational status & Manual workers & 30.47 & 30.70 & 0.52 \\
\hline & Clerks & 50.00 & 53.02 & \\
\hline & White collars & 19.53 & 16.28 & \\
\hline BMI $^{\mathbf{a}}$ & Underweight & 4.40 & 7.91 & 0.10 \\
\hline & Normal & 62.77 & 59.53 & \\
\hline & Overweight & 32.83 & 32.56 & \\
\hline Smoking & Former and current & 38.20 & 47.44 & 0.01 \\
\hline Alcohol & $\geq 0$ gr/day & 80.58 & 80.93 & 0.91 \\
\hline $\begin{array}{l}\text { History of chronic } \\
\text { disorders } b\end{array}$ & Yes & 40.45 & 59.53 & $<0.0001$ \\
\hline Hypertension $^{c}$ & Yes & 55.26 & 64.65 & 0.01 \\
\hline APOE 4 & At least one & 20.60 & 18.14 & 0.42 \\
\hline Depression $^{d}$ & Yes & 26.82 & 31.63 & 0.16 \\
\hline IADL $^{e}$ & $>1$ & 5.79 & 13.95 & $<0.0001$ \\
\hline Fruit and vegetables $f$ & Yes & 32.83 & 29.77 & 0.39 \\
\hline
\end{tabular}


Fish ${ }^{g}$

Olive oil $^{\text {h }}$

Physical activity $^{\text {i }}$

Mild Cognitive

Impairment

Physical frailty *

Age (years)

Fibrinogen $(\mathrm{g} / \mathrm{L})^{* *}$

e-GFR

(mL/mn/1.73m2)

Cystatin C (unit)

$A \beta_{1-40}(\mathrm{pg} / \mathrm{mL})$

$A \beta_{1-42}(\mathrm{pg} / \mathrm{mL})$

$A \beta_{1-40} / 1-42$
Yes

No

Moderate

High

No

Yes

Unknown

Yes

Yes

4.55

$\mathrm{m}(\mathrm{SD})$

21.46

40.45

38.09

58.58

32.40

9.01

42.93
85.58

0.05

30.70

0.01

37.67

31.63

69.30

0.01

22.79

7.91

45.75

0.46

12.75

0.0002

$\mathrm{m}(\mathrm{SD})$
$73.00(4.85) \quad 77.23(5.18) \quad<0.0001$

$3.31(0.67) \quad 3.49(0.72) \quad 0.01$

$76.70(12.28) \quad 71.54(14.82) \quad<0.0001$

$0.87(0.18) \quad 0.99(0.28) \quad<0.0001$

$229.7(51.0) \quad 247.7(52.8) \quad<0.0001$

$38.12(10.19) \quad 39.43(12.15) \quad 0.17$

$6.31(1.86) \quad 6.70(2.16) \quad 0.02$

$* \mathrm{n}=787$ with 149 deceased

***n=1118 with 208 deceased

${ }^{a}$ Body mass index (BMI, underweight $<20 \mathrm{~kg} / \mathrm{m}^{2}$, normal, overweight $\geq 27 \mathrm{~kg} / \mathrm{m}^{2}$ );

b History of chronic disorders at inclusion (cardiovascular diseases, diabetes, chronic bronchitis, dyspnea, thyroid disease and cancer);

${ }^{\mathrm{c}}$ Hypertension (SBP $>160 \mathrm{mmHg}$ or DBP $>95 \mathrm{mmHg}$, or treatment)

${ }^{d}$ Presence of depressive symptoms assessed with the Center for Epidemiological StudiesDepression Scale (CES-D) ${ }^{49}$ including a cut-off of $>16$ or current treatment for depression;

${ }^{\mathrm{e}}$ Limitations in at least one of the instrumental activities of daily living (IADL);

${ }^{\mathrm{f}}$ Fruits or vegetables intake at least once a day;

${ }^{\mathrm{g}}$ Fish/seafood intake at least once a week;

h Olive oil: "no use", "moderate use": using olive oil for cooking or dressing alone or "high" use: using both for cooking and dressing;

${ }^{i}$ Physical activity defined as regular when doing sport, active leisure or household physical activity regularly. 
Table 2: Correlations between biological parameters and age: Spearman coefficient ( $\mathrm{p}$ value)

\begin{tabular}{lrrrrr} 
& $\begin{array}{r}\mathrm{A} \beta 1-40 \\
(\mathrm{pg} / \mathrm{mL})\end{array}$ & $\begin{array}{r}\mathrm{A} \beta 1-42 \\
(\mathrm{pg} / \mathrm{mL})\end{array}$ & $\begin{array}{r}\text { Cystatin C } \\
(\mathrm{unit})\end{array}$ & $\begin{array}{r}\text { Fibrinogen } \\
(\mathrm{g} / \mathrm{L})\end{array}$ & e-GFR $(\mathrm{mL} / \mathrm{mn} / 1.73 \mathrm{~m} 2)$ \\
\hline Age & $0,19(<, 0001)$ & $0,08(0,0048)$ & $0,34(<, 0001)$ & $0,11(0,0001)$ & $-0,32(<, 0001)$ \\
$\mathrm{A} \beta 1-40(\mathrm{pg} / \mathrm{mL})$ & 1 & $0,48(<, 0001)$ & $0,3(<, 0001)$ & $0,03(0,27)$ & $-0,31(<, 0001)$ \\
$\mathrm{A} \beta 1-42(\mathrm{pg} / \mathrm{mL})$ & & 1 & $0,19(<, 0001)$ & $0,05(0,07)$ & $-0,23(<, 0001)$ \\
Cystatin C $(\mathrm{unit})$ & & & 1 & $0,15(<, 0001)$ & $-0,59(<, 0001)$ \\
Fibrinogen $(\mathrm{g} / \mathrm{L})$ & & & & & $-0,09(0,004)$
\end{tabular}

All analyses were performed on 1147 subjects except for fibrinogen performed on 1118 subjects. 
Table 3 (former table 2): Risk of mortality associated with plasma amyloid peptides. (N= 1147 with 215 deceased)

Adjusted hazard ratios (HRs) and 95\% confidence intervals (CI) associated with 1 SD increase.

\begin{tabular}{|c|c|c|c|c|c|c|c|c|}
\hline \multirow[b]{3}{*}{$\mathbf{A} \boldsymbol{\beta}_{1-40}$} & \multicolumn{4}{|c|}{ BASIC } & \multicolumn{4}{|c|}{ CLASSIC CONFOUNDERS } \\
\hline & \multirow{2}{*}{$\begin{array}{l}\text { HR } \\
1.16\end{array}$} & \multicolumn{2}{|c|}{$95 \% \mathrm{CI}$} & \multirow{2}{*}{$\begin{array}{c}\mathrm{p} \\
0.02\end{array}$} & \multirow{2}{*}{$\begin{array}{l}\mathrm{HR} \\
1.15\end{array}$} & \multicolumn{2}{|c|}{$95 \% \mathrm{CI}$} & \multirow{2}{*}{$\begin{array}{c}\mathrm{p} \\
0.03\end{array}$} \\
\hline & & 1.02 & 1.32 & & & 1.01 & 1.31 & \\
\hline $\mathbf{A} \boldsymbol{\beta}_{1-42}$ & 1.02 & 0.90 & 1.16 & 0.73 & 1.00 & 0.88 & 1.13 & 0.97 \\
\hline Ratio $A \beta_{1-40 / 1-42}$ & 1.08 & 1.01 & 1.15 & 0.02 & 1.08 & 1.02 & 1.15 & 0.012 \\
\hline
\end{tabular}

BASIC $=$ Age, gender, study center

CLASSICAL CONFOUNDERS = BASIC + educational level, occupation, BMI, smoking status, alcohol, history of chronic disorders, hypertension, depression, IADL, fruits and vegetables, fish, olive oil intake and physical activity. 
Table 4 (former table 3): Risk of mortality associated with plasma amyloid peptides: impact of possible mediators.

Adjusted hazard ratios (HRs) and 95\% confidence intervals (CI) associated with 1 SD increase.

\begin{tabular}{|c|c|c|c|c|c|c|c|c|}
\hline \multirow[b]{3}{*}{$\mathbf{A} \boldsymbol{\beta}_{1-40}$} & \multicolumn{4}{|c|}{ MCI } & \multicolumn{4}{|c|}{ FRAILTY } \\
\hline & \multirow{2}{*}{$\begin{array}{l}\text { HR } \\
1.15\end{array}$} & \multicolumn{2}{|c|}{$95 \% \mathrm{CI}$} & \multirow{2}{*}{$\begin{array}{c}\mathrm{p} \\
0.03\end{array}$} & \multirow{2}{*}{$\begin{array}{l}\text { HR } \\
1.21\end{array}$} & \multicolumn{2}{|c|}{$95 \% \mathrm{CI}$} & \multirow{2}{*}{$\begin{array}{c}\mathrm{p} \\
0.02\end{array}$} \\
\hline & & 1.01 & 1.31 & & & 1.04 & 1.40 & \\
\hline $\mathbf{A} \boldsymbol{\beta}_{1-42}$ & 1.00 & 0.88 & 1.13 & 0.95 & 1.03 & 0.89 & 1.19 & 0.70 \\
\hline \multirow[t]{3}{*}{ Ratio $A \beta_{1-40} / 1-42$} & 1.08 & 1.02 & 1.15 & 0.01 & 1.09 & 1.02 & 1.17 & 0.02 \\
\hline & \multicolumn{4}{|c|}{ CYSTATIN C } & \multicolumn{4}{|c|}{ FIBRINOGEN } \\
\hline & HR & \multicolumn{2}{|c|}{$95 \% \mathrm{CI}$} & $\mathrm{p}$ & HR & \multicolumn{2}{|c|}{$95 \% \mathrm{CI}$} & $\mathrm{P}$ \\
\hline $\mathbf{A} \boldsymbol{\beta}_{1-40}$ & 1.10 & 0.96 & 1.25 & 0.17 & 1.17 & 1.02 & 1.33 & 0.02 \\
\hline $\mathbf{A} \boldsymbol{\beta}_{1-42}$ & 0.97 & 0.86 & 1.10 & 0.62 & 1.00 & 0.88 & 1.13 & 0.94 \\
\hline \multirow[t]{3}{*}{ Ratio $A \beta_{1-40} /{ }_{1-42}$} & 1.08 & 1.01 & 1.15 & 0.02 & 1.09 & 1.03 & 1.16 & 0.007 \\
\hline & \multicolumn{4}{|c|}{ KIDNEY FUNCTION } & & & & \\
\hline & HR & \multicolumn{2}{|c|}{$95 \% \mathrm{CI}$} & $\mathrm{P}$ & & & & \\
\hline $\mathbf{A} \boldsymbol{\beta}_{1-40}$ & 1.14 & 1.00 & 1.31 & 0.05 & & & & \\
\hline $\mathbf{A} \boldsymbol{\beta}_{1-42}$ & 0.98 & 0.87 & 1.11 & 0.77 & & & & \\
\hline Ratio $A \beta_{1-40} / 1-42$ & 1.08 & 1.02 & 1.15 & 0.01 & & & & \\
\hline
\end{tabular}


All analyses were performed for the whole sample ( $\mathrm{n}=1147$ with 215 deceased) except for the two models: FRAILTY (n=787 with 149 deceased) and FIBRINOGEN (n=1118 with 208 deceased).

CLASSICAL CONFOUNDERS = BASIC + educational level, occupation, BMI, smoking status, alcohol, history of chronic disorders, hypertension, depression, IADL, fruits and vegetables, fish, olive oil intake and physical activity.

MCI= CLASSICAL CONFOUNDERS + MCI or prevalent dementia status.

FRAILTY= CLASSICAL CONFOUNDERS + frailty status.

CYSTATIN $=$ CLASSICAL CONFOUNDERS + Cystatin C

FIBRINOGEN= CLASSICAL CONFOUNDERS + Fibrinogen.

KYDNEY FUNCTION= CLASSICAL CONFOUNDERS + e-GFR. 


\section{FIGURES LEGEND Gabelle et al., manuscript}

Figure 1: Flow Chart of the present study.

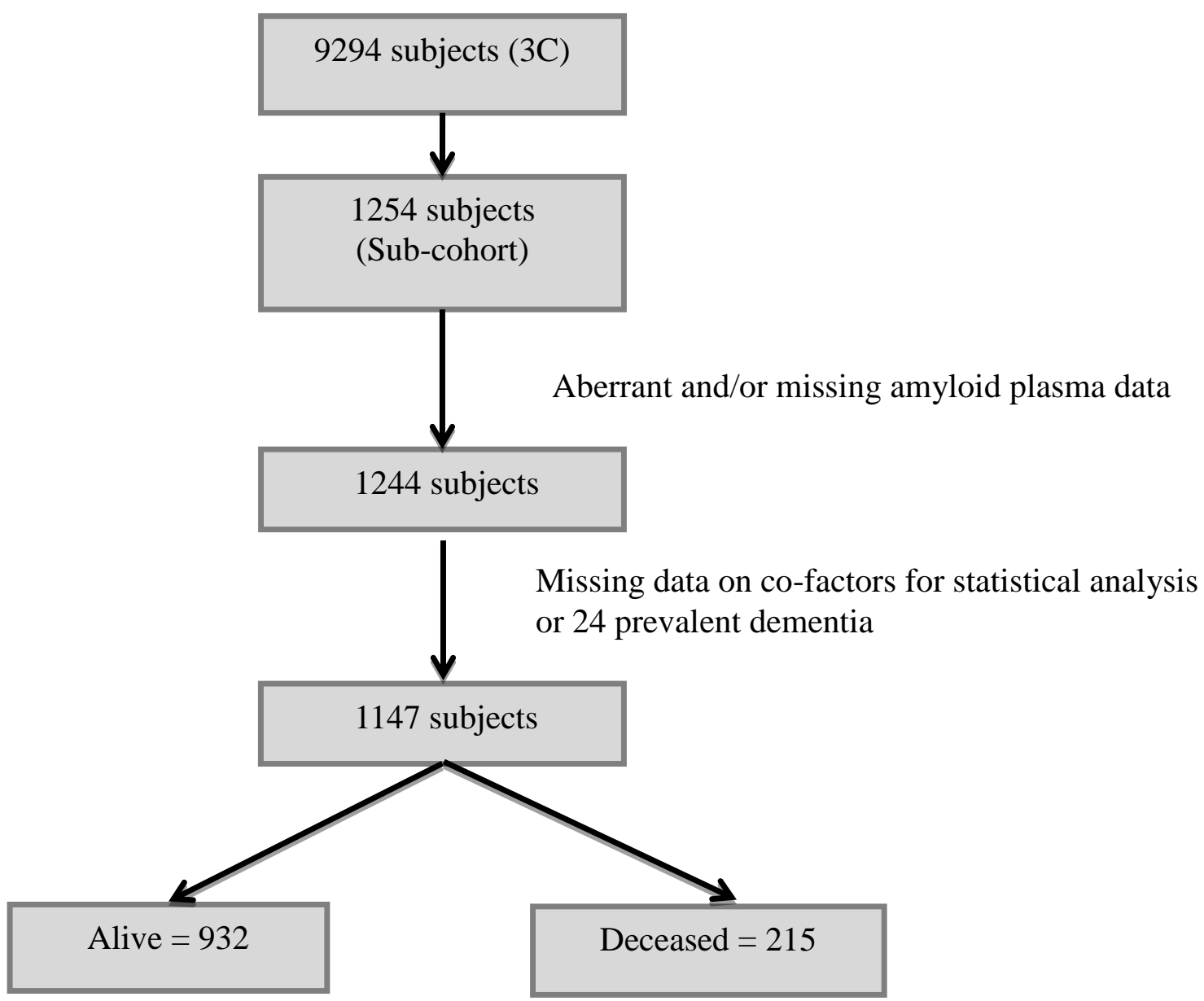


Figure 2: Kaplan-Meyer survival curves for death in 1147 of the 3C study subjects (215 died during follow up) according to plasma $\beta$ amyloid levels (Figure $2 \mathrm{~A}$ for $\mathrm{A} \beta \mathrm{1}_{1-40}$, Figure $2 B$ for $A \beta_{1-42}$ ).

Figure 2 A

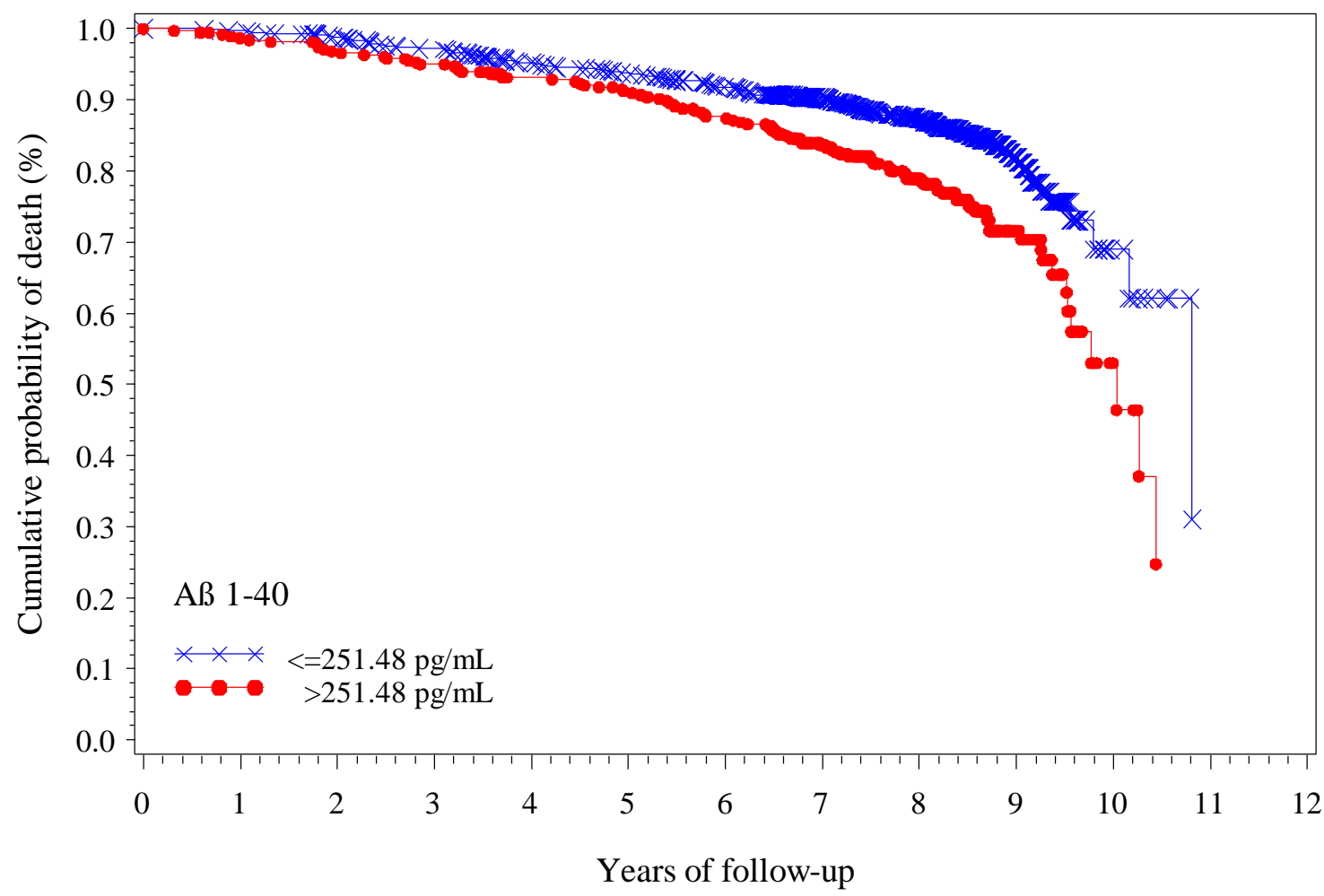

(Tertile $1+$ Tertile 2 ) versus Tertile 3 
Figure $2 \mathrm{~B}$

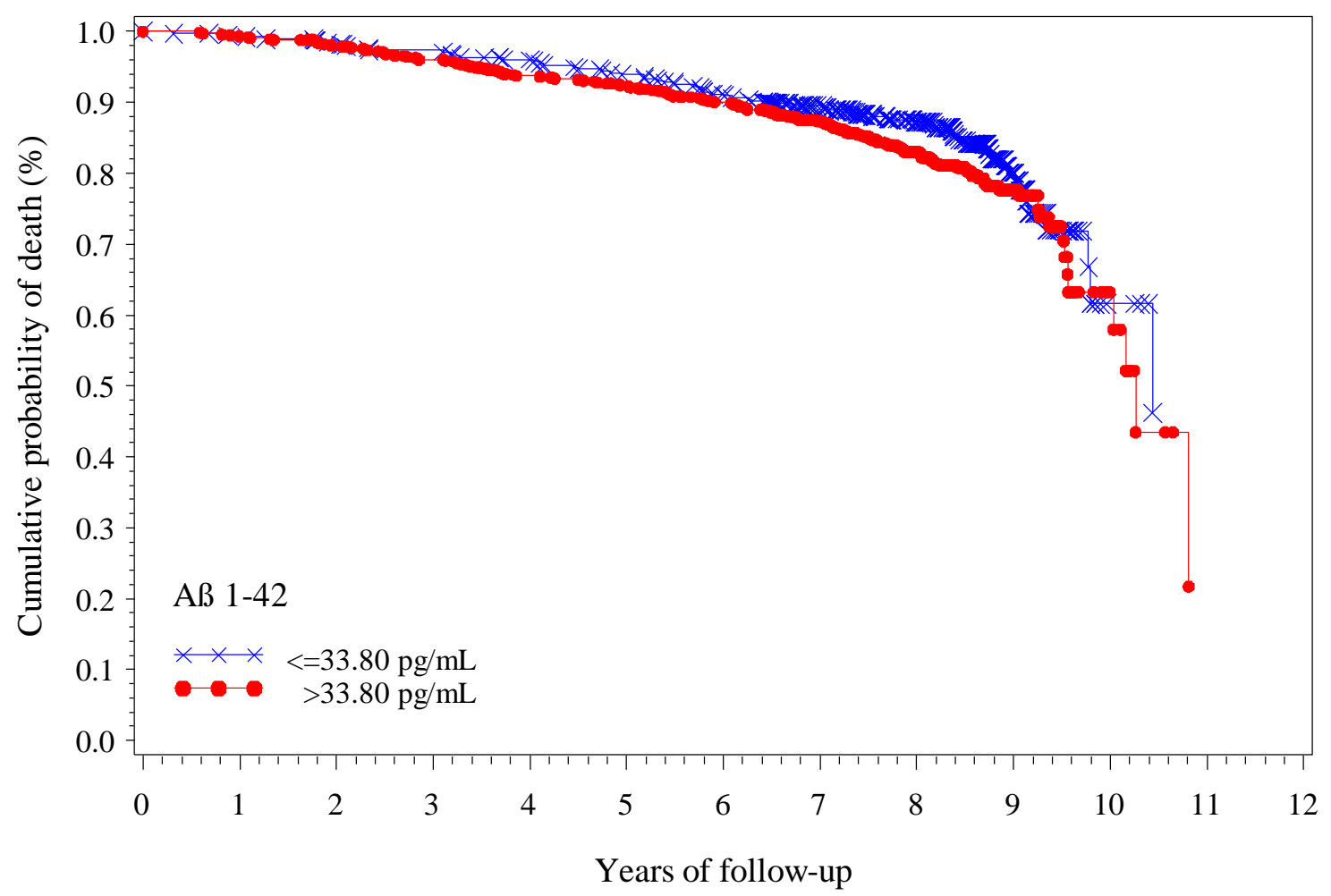

Tertile 1 versus (Tertile $2+$ Tertile 3 ) 